\title{
A SCANNING ELECTRON MICROSCOPE STUDY OF FLOWERS OF AVOCADO, LITCHI, MACADAMIA AND MANGO
}

\author{
P.B. SCHOLEFIELD \\ CSIRO, Division of Horticultural Research, PMB 44, Winnellie, N.T. 5789 (Australia)
}

(Accepted for publication 12 August 1981)

\begin{abstract}
Scholefield, P.B., 1982. A scanning electron microscope study of flowers of avocado, litchi, macadamia and mango. Scientia Hortic., 16: 263-272.

Flowers of the avocado (Persea americana Mill. cultivar 'Fuerte'), litchi (Litchi chinensis Sonn. cultivar 'Brewster'), macadamia (Macadamia integrifolia Maiden and Betche cultivar 'Hinde') and mango (Mangifera indica L. cultivar 'Haden') were examined using the scanning electron microscope (SEM). Micrographs of whole flowers and floral parts are presented. The SEM shows the floral structure in more detail than has been possible with light microscopy. Relationships between structure and function are discussed
\end{abstract}

\section{INTRODUCTION}

The tropical/sub-tropical species avocado (Persea americana Mill.), litchi (Litchi chinensis Sonn.), macadamia (Macadamia integrifolia Maiden and Betche) and mango (Mangifera indica L.) are all horticultural crops with economic potential but, apart from the mango, none of them can be classed as a major horticultural crop world-wide. A relatively small amount of research has been done on these species, and breeding-programs in particular are in their infancy. Most new cultivars have arisen from selections of openpollinated seedlings, rather than from deliberate crosses. A thorough understanding of the floral biology and pollination requirements is needed before effective breeding can commence.

The scanning electron microscope (SEM) has been shown by Troughton and Donaldson (1972) and many others to be an excellent tool for presenting detail of plant structure with great depth of focus. Thus whole flowers and floral parts can be photographically presented in more detail than has been possible with light microscopy.

This paper contains scanning electron micrographs of the floral structure of the avocado, litchi, macadamia and mango, which should give plant breeders and horticulturists a greater appreciation of the floral biology of these fruit and nut species. 


\section{MATERIALS AND METHODS}

Plant material. -- Grafted trees of avocado ('Fuerte', 10 years old), macadamia ('Hinde', 10 years old) and mango ('Haden', 3 years old) were growing in the orchards of CSIRO, situated at Merbein in north-west Victoria (latitude $34^{\circ} \mathrm{S}$ ). The grafted litchi ('Brewster', 3 years old) was growing in 10-1 pots in a shadehouse. Flowering was observed in spring and flowers were picked and placed in a petri dish with moist filter paper.

SEM procedure. - Whole flowers were mounted fresh and uncoated on a spike inserted into an aluminium SEM stub and examined in a Philips PSEM 500 scanning electron microscope using an accelerating voltage of $6 \mathrm{kV}$ and a spot size of $125 \mathrm{~nm}$. With some specimens, up to $30 \mathrm{~min}$ observation was possible in the microscope before desiccation effects became obvious.

\section{RESULTS AND DISCUSSION}

Avocado (Fig. 1). -- The avocado inflorescence arises from terminal or axillary positions on the shoot and is classed as a cymose panicle. The anatomical development and embryology of the flower was described by Schroeder (1952), while Reece $(1939,1942)$ described the differentiation and floral anatomy.

Flowers are perfect, regular and trimerous. The perianth consists of an outer whorl of 3 sepals and an inner whorl of 3 similar petals, followed by 3 whorls each of 3 stamens and an inner whorl of 3 shorter staminodes. Either side of the stamens of the inner whorl is a yellow/orange nectary. The staminodes are sterile anthers on short filaments, which also secrete nectar and together with the nectaries are important for insect attraction.

Flowers exhibit marked dichogamy (Robinson and Savage, 1926), opening first as a female with receptive stigma and then closing to re-open as a male when the pollen is released. Two groups of cultivars have complementary flower types called Types A and B. Type A opens as a female flower in the morning, closing to re-open as a male in the afternoon of the following day, whereas Type $B$ opens as a female in the afternoon and as a male the following morning. Thus pollen from the male stage is available to pollinate the receptive stigma of the female stage of the complementary flower type.

The different stages of opening of the avocado flower are presented in Fig. 1. An open flower in the female stage (1A) has the stamens reflexed and the ovary, style and stigma clearly visible. Many papillae cover the stigmatic

Fig. 1. Avocado. A. Flower in the female stage. Note the reflexed anthers, staminodes $(\mathrm{S})$, nectaries $(\mathrm{N})$, ovary $(\mathrm{O})$ and stigma $(\mathrm{ST})(\times 8)$. B. Stigma surface with papillae $(X 86)$. C. Anther attached to hairy filament. Note valves $(V)$ hinged at top $(X 25)$. D. Staminode $(S)$ and 2 nectaries $(N)(\times 22)$. E. Flower in the male stage. Stamens now surround the style and stigma and all anthers have dehisced $(\times 6.5)$. F. Dehisced anther $(X 27.5)$. G. Pollen grain $(X 1000)$. H. Pollen clumped on valve $(X 65)$. 

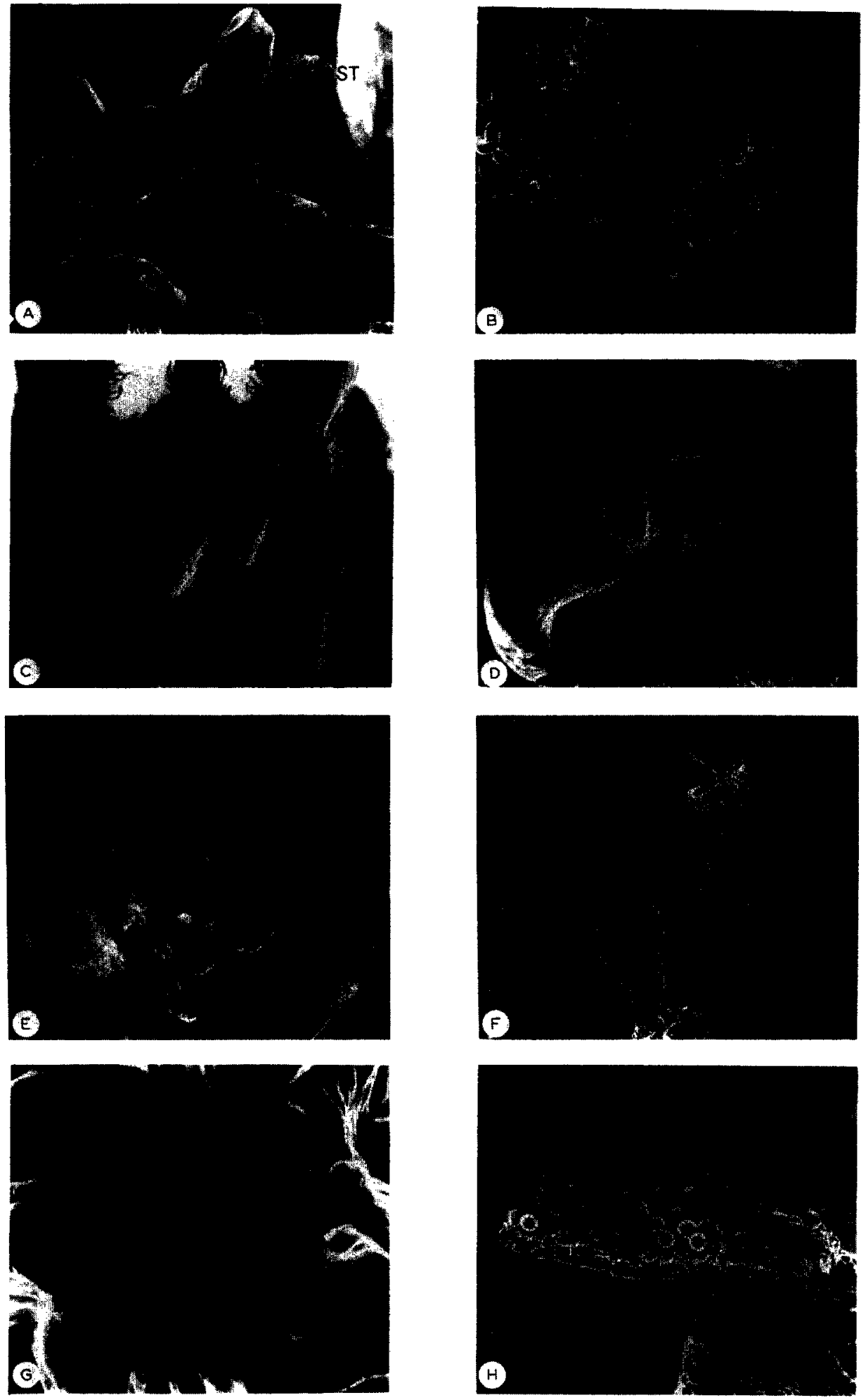

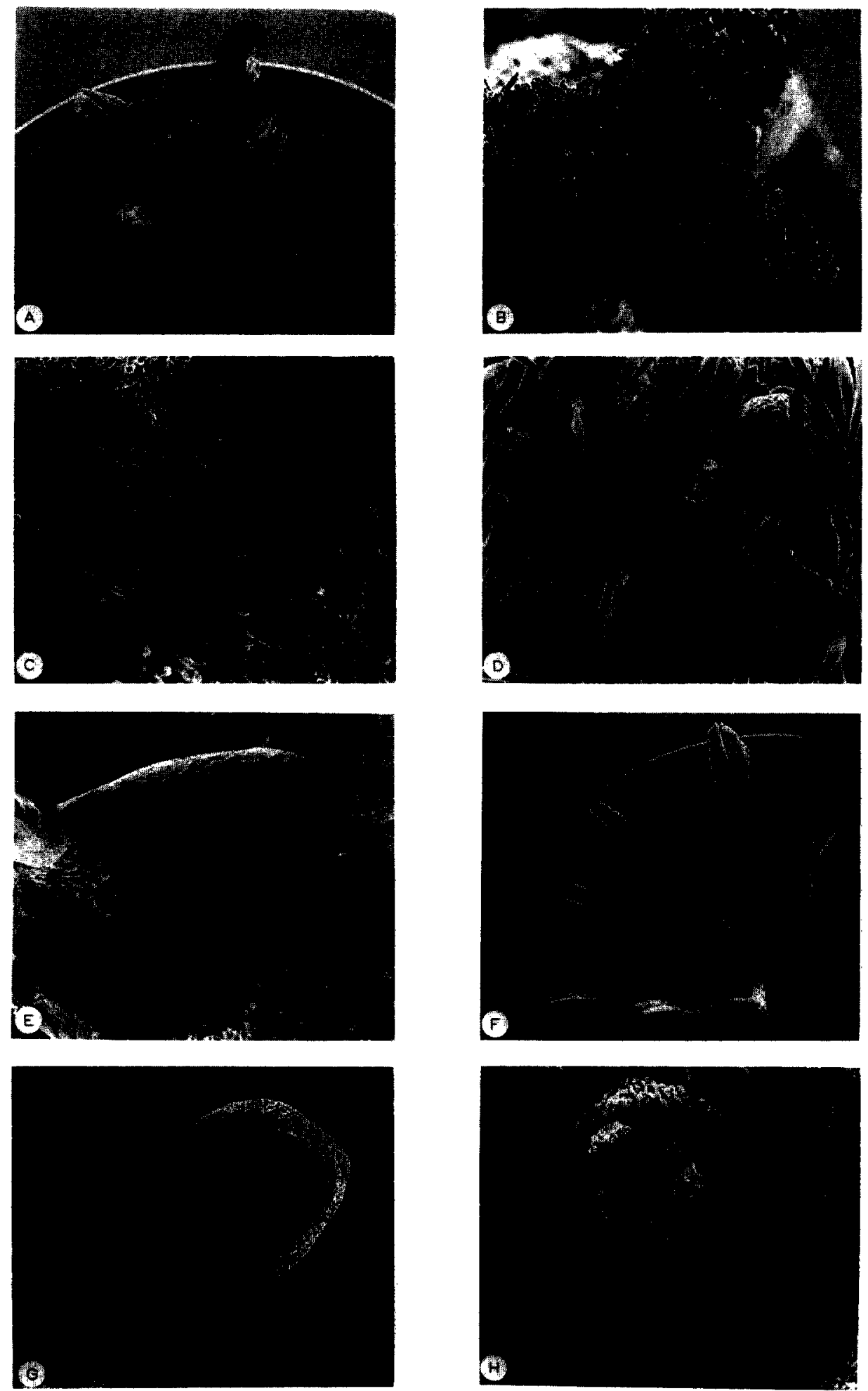
surface (1B) and extend down a groove in the style that is lined with transmitting tissue (Sedgley and Buttrose, 1978). The anthers are intact with the 4 hinged valves closed (1C) and the nectaries and staminodes (1D) are moist with secretion.

In the male stage of the flowering-cycle $(1 \mathrm{E})$, the whorls of stamens surround the style and stigma and the valves dehisce $(1 \mathrm{~F})$, releasing the pollen (1G) which clumps together $(1 \mathrm{H})$.

Litchi (Fig. 2). - - The litchi inflorescence is a terminal panicle of many small flowers. Floral differentiation and ontogeny were described by Shukla and Bajpai (1974).

Three types of flower occur in succession on the same inflorescence (Khan, 1929; Nakata, 1950). In order of appearance they are: (i) hermaphrodite with an abortive ovary (functionally male); (ii) hermaphrodite with small, infertile stamens (functionally female); (iii) male.

All flowers have 4 or 5 very small sepals, but lack petals. The functionally female flowers (2A) have a well developed ovary and stigma and infertile anthers on short filaments. The ovary may consist of 2 or 3 carpels, each with its own stigmatic lobe (2B). Usually, only one carpel develops into a fruit and the others may remain undeveloped but attached to the fruit at maturity. The stigmatic surfaces have many papillae (2B), and these extend down a groove in the style (2C). The ovary surface is pubescent and has protuberances on the surface (2D) which persist and give the mature fruit its rough surface. At the base of the ovary the nectar disc with secretion (2E) probably attracts insects. The hermaphrodite, but functionally male, flowers (2F) have variable numbers of stamens, usually between 6 and 10 . The anthers (2G) dehisce longitudinally, releasing pollen, and the ovary $(2 \mathrm{~F}, 2 \mathrm{H})$ is small and without a functional stigma (cf. $2 \mathrm{~A}$ ). These flowers also have a nectar disc at the base but it is less developed than in the functionally female flower.

No flowers of the male type are shown. They are similar to $2 \mathrm{~F}$ but without the abortive ovary.

Self pollination can occur on the same tree because within the same inflorescence and between different inflorescences, male and female flowers can be open at the same time.

Macadamia (Fig. 3). - Macadamia flowers are borne in pairs on the axis of a raceme. They are a perfect, tubular flower with a swollen distal end (3A).

Fig. 2. Litchi. A. Functionally female flower with small anthers on short filaments. Note the ovary has 3 carpels and a 3 -lobed stigma $(\times 6.5)$. B. Stigmatic surface with papillae $(X 22.5)$. C. Portion of the stigma surface showing the papillae in the groove in the style $(X 45)$. D. Pubescent surface of the ovary. Note hte protuberances $(P)(X 100)$. E. Nectary $(N)$ at the base of the ovary with secretion $(X 22.5)$. F. Functionally male flower ( $\times$ 5.5). G. Anther ( $\times$ 25). H. Abortive ovary ( $\times$ 22.5). 

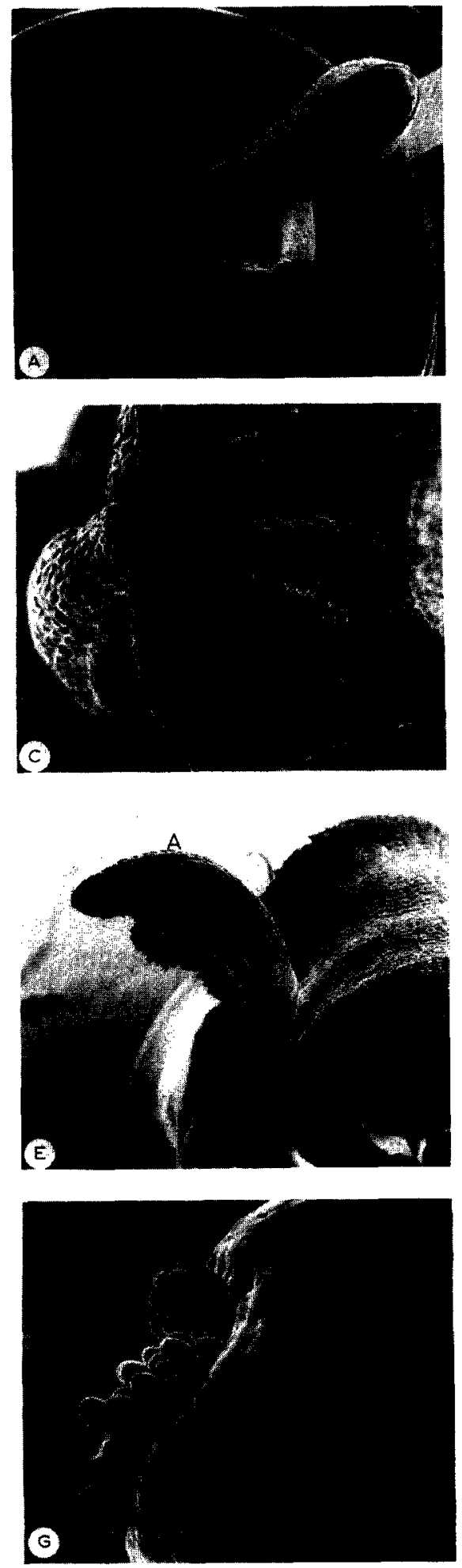
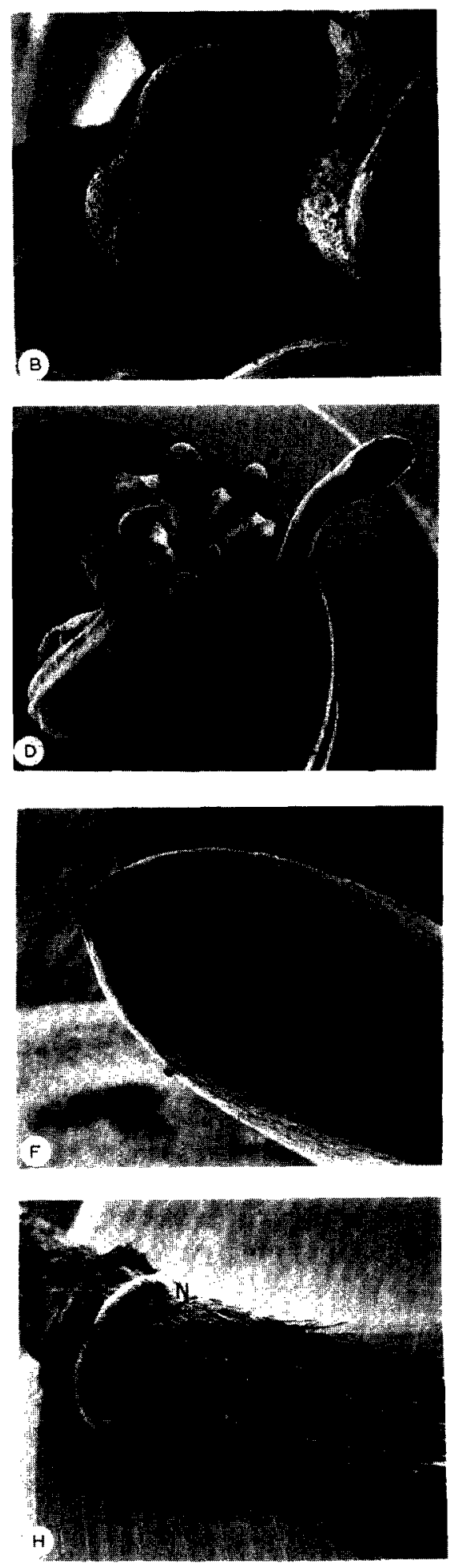
The floral structure and anatomy were previously described by Kausik (1938) and Urata (1954), and the stages of opening of the flower were depicted by Vogel (1957). The perianth consists of 4 sepals interlocked along their margins (3A). The style elongates before anthesis, bends because of the restriction within the flower, and breaks through the suture between the sepals (3A) giving the typical appearance of many flowers in the family Proteaceae. Sepal separation occurs from the tip, exposing the 4 anthers joined at their apex $(3 \mathrm{~B}, 3 \mathrm{C})$. Anther dehiscence releases the tetrahedralshaped pollen, which adheres to the stigma/style in clumps before anthesis (3C). The sepals curve back releasing the style with its club-shaped tip (3D). Anthers are curved and attached part way up the sepals by a short filament $(3 E)$. The receptive stigmatic area forms only a very small portion of the glabrous, club-shaped end of the style (3F) and is composed of papillae $(3 G)$ which extend down a furrow in the style (Kausik, 1938). A nectary is present at the base of the pubescent ovary $(3 \mathrm{H})$.

The method of pollen deposition on the stigma/style area before anthesis suggests a self-pollination mechanism, but Urata (1954) presented evidence that partial self-incompatibility was present in some cultivars. The presence of the nectary also indicates that insects function in cross-pollination.

Mango (Fig. 4). - The mango infloressence is a terminal panicle with large numbers of hermaphrodite and male flowers on the same inflorescence. In his general review, Singh (1969) discussed the floral biology of the mango and illustrated these flower types. Detailed floral morphology was described by Juliano and Cuevas (1933) for 'Pico'.

Hermaphrodite flowers (4A, 4B) have a 10-part perianth consisting of 5 sepals and 5 petals. The round carpel is supported on a 5-lobed nectary (4C). The short style has a small stigmatic surface (4D) without the prominent papillae of the other stigmas described in this paper. The groove in the style (4D) appears to be a factor in common with the avocado, litchi and macadamia. One fertile stamen and 4 short infertile staminodes are present. Male flowers (4E) are similar to the hermaphrodite flowers except that the carpel has aborted. The single, 4-lobed anther (4F) dehisces longitudinally (4G) releasing pollen. The staminodes $(4 \mathrm{H})$ consist of a lobed mass of tissue on a short filament.

Mango is considered to be a cross-pollinated plant (Allard, 1960; Mukherjee, 1953) with flies as the pollinating agent.

Fig. 3. Macadamia. A. Single flower with style protruding through gap in sepals $(\times 7)$. $B$. Sepal tips opened showing anthers attached at apex $(x 27.5)$. C. Anthers dehisced before stigma protrudes $(X 50)$. D. Open flower with sepals reflexed and style and stigma free $(\times 6.5)$. E. Curved anther $(A)$ with short filament attaching to sepal $(X 25)$. F. Elongated bulbous end of style with small stigma ( $\times$ 62.5). G. Papillae on stigma $(\times 250)$. $H$. Flower with perianth removed showing pubescent ovary with nectary $(N)$ at base $(\times 22.5)$. 

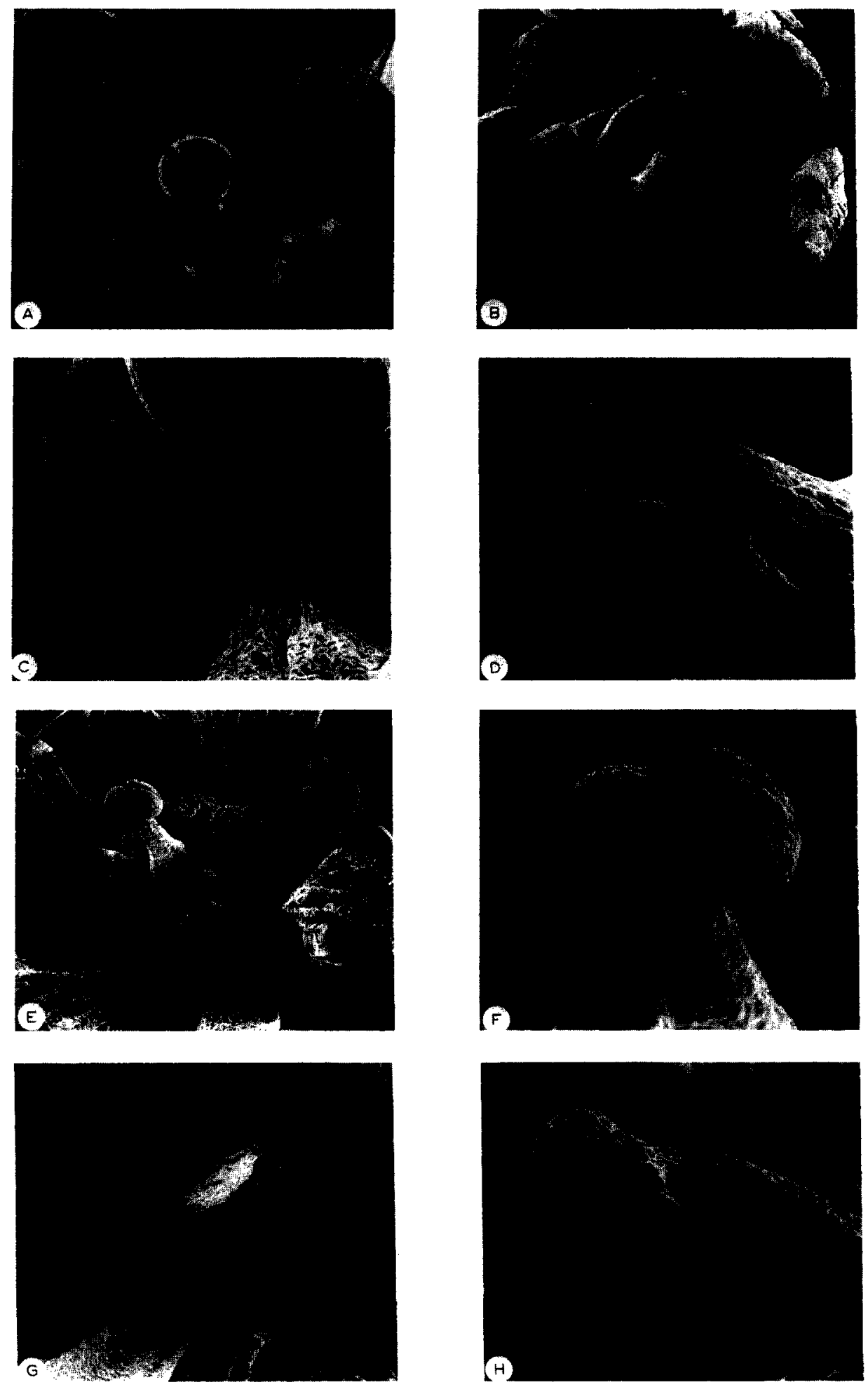


\section{CONCLUSONS}

The flowers described herein exhibit some form of separation of the sexes, although the species are all monoecious. This separation may be by perfect flowers having their male and female stages separated by time (avocado), with the stigma being unreceptive when the pollen is released and vice versa, or by the flowers being functionally male or female (litchi). Although some mango and all macadamia flowers are perfect, evidence has been presented (Urata, 1954; Ito and Hamilton, 1980; Sharma and Singh, 1970) that some degree of self incompatibility exists in these species. Whether self incompatibility exists or not with the avocado and litchi, cross pollination is required, either on the same tree or between different trees.

Therefore, it is essential that pollen from one flower is transmitted to the receptive stigma of another for successful pollination, fertilization and fruit production. All the flowers described possess nectaries, and this indicates that insects are the vector for cross pollination (McGregor, 1976). The small stigmatic area of the mango and macadamia, and to a lesser extent the avocado, discount the possibility of wind pollination. The clumping of pollen in the avocado $(1 \mathrm{H})$ also suggests insect pollination.

A better understanding of the peculiarities of the floral structure and biology will allow us better to manipulate the flowering-period, either by the use of pollinating insects for increasing yield or by increasing the efficiency of hybridising in controlled-pollination breeding-programs.

\section{ACKNOWLEDGEMENTS}

I wish to acknowledge the photographic assistance of Mr. E.A. Lawton, and the helpful discussions with Dr. M. Sedgley.

\section{REFERENCES}

Allard, R.W., 1960. Principles of Plant Breeding. John Wiley, New York, 485 pp.

Ito, P.J. and Hamilton, R.A., 1980. Quality and yield of Keauhou macadamia nuts in mixed and pure block plantings. HortScience, 15: 307 .

Juliano, J.B. and Cuevas, N.L., 1933. Floral morphology of the mango (Mangifera indica Linn.) with special reference to the Pico variety from the Philippines. Philipp. Agric., 21: 449-472.

Kausik, S.B., 1938. Studies in the Proteaceae. II. Floral anatomy and morphology of Macadamia ternifolia F. Muell. Proc. Indian Acad. Sci., Sect. B, 8: 45-62.

\footnotetext{
Fig. 4. Mango. A. Hermaphrodite flower showing 5-partite calyx and corolla, nectaries, carpel and single stamen $(\times 6.5)$. B. Hermaphrodite flower $(\times 12.5)$. C. Nectary $(N)$ at base of ovary (X 22.5). D. Stigma (ST) and portion of style $(\times 200)$. E. Male flower with single stamen and infertile staminodes $(x 11.5)$. F. Anther $(X 50)$. G. Anther showing mode of dehiscence $(\times 50)$. H. Staminode $(\times 100)$.
} 
Khan, K.S.A.R., 1929. Pollination and fruit formation in Litchi. Agric. J. India, 24: $183-187$.

McGregor, S.E., 1976. Insect Pollination of Cultivated Crop Plants. U.S. Dep. Agric., Agric. Handb. No. 496, 411 pp.

Mukherjee, S.K., 1953. The Mango - its botany, cultivation, uses and future improvement, especially as observed in India. Econ. Bot., 7: 130-162.

Nakata, S. and Watanabe, Y., 1966. Effects of photoperiod and night temperature on the flowering of Litchi chinensis. Bot. Gaz., 127: 146-152.

Reece, P.C., 1939. The floral anatomy of the avocado. Am. J. Bot., 26: 429-433.

Reece, P.C., 1942. Differentiation of avocado blossom buds in Florida. Bot. Gaz., 104: $323-328$.

Robinson, T.R. and Savage, E.M., 1926. Pollination of the Avocado. U.S. Dep. Agric., Circ. 387.

Schroeder, C.A., 1952. Floral development, sporogenesis, and embryology in the avocado. Persea americana. Bot. Gaz., 113: 270-278.

Sedgley, M. and Buttrose, M.S., 1978. Structure of the stigma and style of the avocado. Aust. J. Bot., 26: 663-682.

Sharma, D.K. and Singh, R.N., 1970. Self-incompatibility in mango (Mangifera indica L.). Hortic. Res., 10: 108-118.

Shukla, R.K. and Bajpai, P.N., 1974. Blossom-bud differentiation and ontogeny in litchi (Litchi chinensis Sonn.). Indian J. Hortic., 31: 224-228.

Singh, L.B., 1969. Mango. In: F.P. Ferwerda and F. Wit (Editors), Outlines of Perennial Crop Breeding in the Tropics. Misc. Pap. Landbouwhogesch. Wageningen, 4: 309-327.

Troughton, J. and Donaldson, L.A., 1972. Probing Plant Structure. A.H. and A.W. Reed, Wellington, $116 \mathrm{pp}$.

Urata, U., 1954. Pollination requirements of macadamia. Hawaii Agric. Exp. Stn. Tech. Bull. 22; 40 pp.

Vogel, R., 1957. Quelques observations sur la floraison de Macadamia ternifolia. Fruits, 12: 50-52. 